\title{
سلطة القاضي في تعديل الأجل في القانون المدني الأردني
}

\author{
shel
}

د / مراد مدحمود شنيـكات د / ماهر جابر الجابر

أستاذ القانون المدني المشارك، قسم المئ القانون، جامعت البلقاء التطبيقيت المتاذيت أستاذ القانون التجاري المساعد، قسم القانون، جامعت البلقاء التطبيقيت المياءئ

د / عاطف سالم العواملث دأسماء مصطفى غنيمات

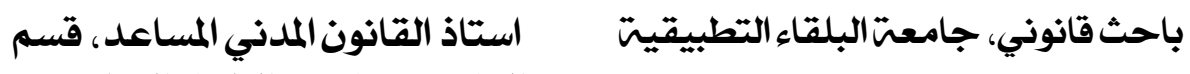

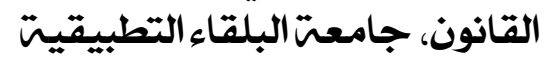




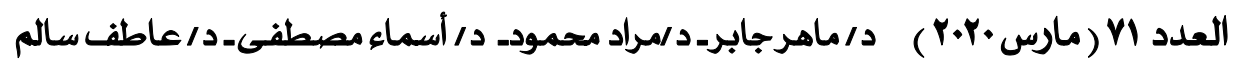

\section{s)}

يتوجب على المدين أن يفي بالتزامه بمجرد حلول أجل الوفاء به ويغض النظر إن كان هذا الالتزام تجارياأو مدنياً. إلا أن المدين قد يواجه في بعض الأحيان ظروفاً معينة تمنعه من الوفاء بالتزامه في موعده ما يخول القاضي منحه مهلة للوفاء بالالتزام في أحوال معينة نص عليها القانون، وهي ما تسمى بالمهلة القضائية أو نظرة الميسرة. إن هذه الدراسة تهدف إلى التعرف على مـدى امـتلاك القاضـي للسلطة التقديريـة في تعديل أجل الوفـاء ومـنح نظرة الميسرة؟ فبإن كـان القاضي يمتلك تلكك السلطة فمـا هي الشروط التي حددها القانون والتي تخوله ممارسة مثل ذلك الحق؟ وهل تعتبر تلك السلطة الممنوحة للقاضي لإعطاء مثل تلكل المهلة خاضعة لرقابة محكمة التمبيز أم لا؟

لقــ اتبع البـاحثون في هذه الدراسـة المـنهج الوصفي واللذي يرتكز على التحليل والتفسير مـن خـلال استعر اض مفهوم الأجل وشروطه، ومن ثم البحث في تعريف المهلة القضائية واستعراض الثروط التي يجب توافرها ليتمكن القاضي من تعديل الأجل بحيث يعطي المدين مهلة قضائية ليتمكن من الوفاء بالتزامه. 


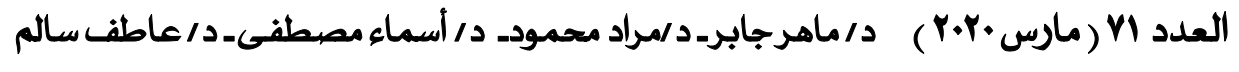

\section{Abstract}

The debtor is obliged to pay off his obligation in the due time with no regards if the obligation is civil or commercial. But, at that time the debtor may face extraordinary circumstances that make him unable to pay it; that give a judge the power to extend a time of payment for an extra time subject to determined matters that mentioned in the law. This period named as payment respite or a judicial respite.

The current research aims to investigate of whether the judge has a legal capability to amend a due time of payment and give a debtor an extra time for payment his obligation? And, if the judge has such power; what are the legal conditions that grant him a power to amend the time of payment? And, what is the role of Supreme Court in the censorship of the judge decision.

To achieve the goal of this research, the researchers follow the descriptive paradigm that concentrates on the analytical and explanation methods to discuss the definition of respite phenomenon and its conditions that grant the judge such of power to give a debtor an extra time for payment. 


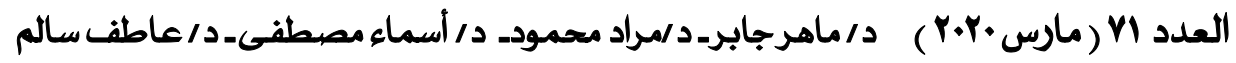

\section{هقدمة}

الأصل في الالتزامسات التي يرتبها العقد الصحيح أن يتم الوفاء بها فور إبرام

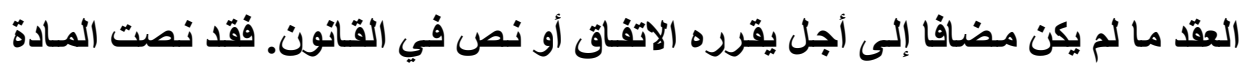

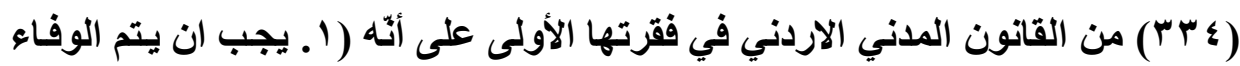

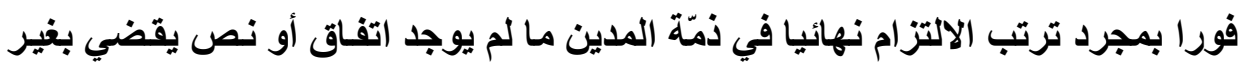

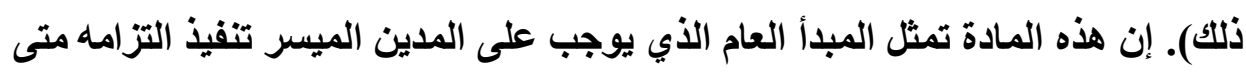
توافرت شروط الوفاء به، ولكن ذلك المدين قد يتعرض في بعض الأحيان إلى عقبات

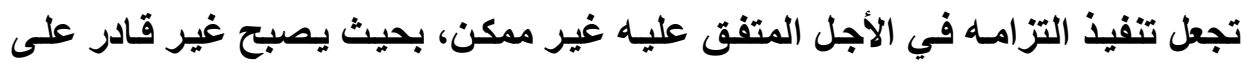
الوفاء به فيلجأ إلى طلب منده أجلاً اضافياً من القاضي ليتمكن من تنفيذ ما على عاتقله من التزام. فالأجل الذي يطلبه المدين في هذه الحالة يكون إضـافة إلى الأجل الذي كان الذان

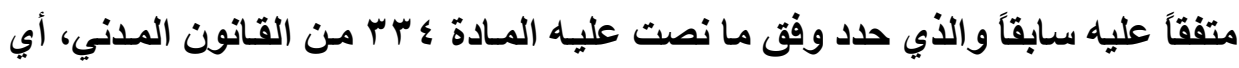
بمجرد ترتب الالتزام نهائياً.

لذلك فقد تلدل المشرع الأردني لتلك المسألة ونظم فكرة الأجل في القـانون

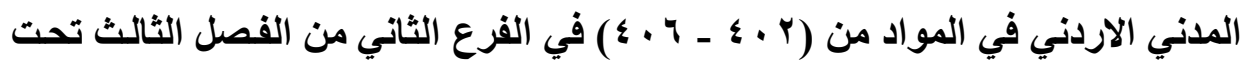

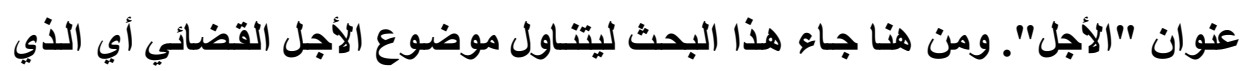
يمنحه القاضسي للمدين ليتمكن من تنفيذ التزامسه والتي تعرف بنظرة الميسرة، حيث اشترط المشرع وجوب تو افر عدة شروط حتى يمنح القاضي للمدين ذلك الأجل. 


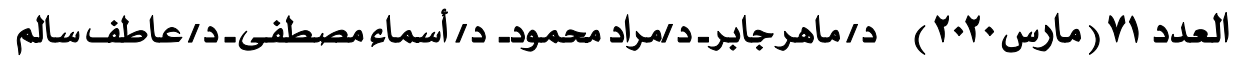

أهمية الدراسة وأهد|فها:

تتبع أهمية الدراسة من خلال البحث في القيود الواردة في النصوص القانونية على العمل بالإستثناء على القاعدة العامة التي نصت على أن العقد شريعة المتعاقدين والتي توجب على المتعاقدين الوفاء بالتزاماتهما في الالتزام بمجرد ترتب الالتزام وفي الأجل المتفق عليه بين المتعاقدين. حيث يمنح هذا الإستثناء للقاضي سلطة تعديل الاجل

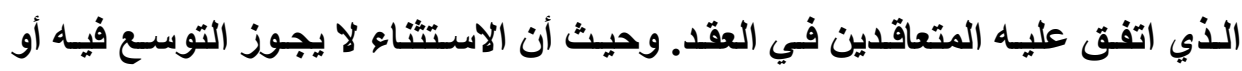
القياس عليه فقد برزت أهمية هذه الاراسة.

وعليه فيان هذه الدراسة تهدف إلى التعرف على المقصود بالأجل من خلال

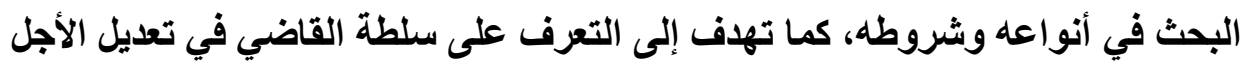

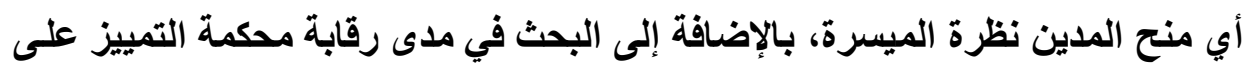

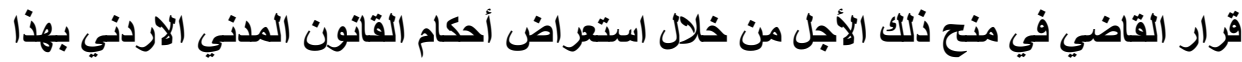
الخصوص. - ا.

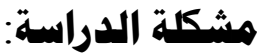

تكمن مشكلة الاراسة في البحث في مدى سلطة القاضي التقايرية في مخالفة

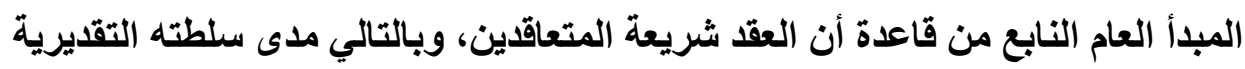

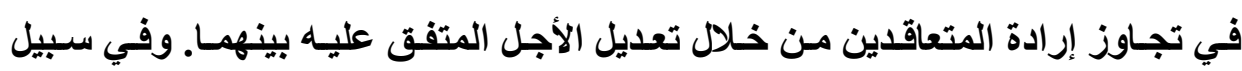
تحقيق ذلك فإن هذه الدراسة سوف تجيب عن تلك الإثمالية من خلال الإجابة عن عدد الإن

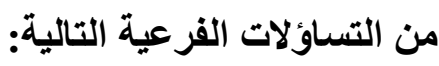
ا ـ ما هي الشروط الواجب توافرهـا ليمنح نظرة الميسرة للمدين؟ بالإضـافة إلى

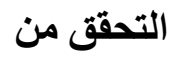

r. مدى رقابة محكمة التمييز على قرار القاضي بتعديل الاجل؟

مجلتّ البحوث القانونيت والإقتصاديت 


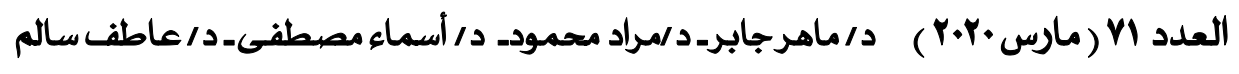

\section{هنههج البشث:}

اعتمدت هذه الدراسة للإجابة عن إثكالية البحث على المنهج الوصفي التحليلي

الأي يرتكز على التحليل والتفسير من خلال استعر اض أحكام القانون الأردني والأحكام القضائية الخاصة بهذا الموضوع من خلال البحث في مفهوم الأجل وشروطه، ومن ثم البحث في تعريف المهلة القضائية واستعراض الشروط التي يجب توفرهـا ليتمكن القاضي من استخدام سلطته في تعديل الأجل بحيث يعطي المدين مهلة قضائية ليتمكن

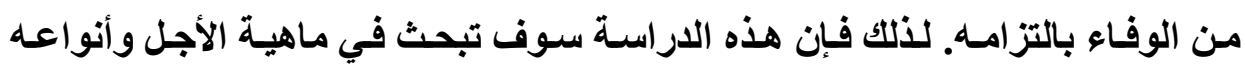
وشروطه (المبحث الأول)، وبعد ذلك سوف يتم البحث في سلطة القاضسي في تعديل

الأجل (المبحث الثاني). 
العدد ال (مارس_r.r.r) د/ماهرجابر-د/مراد محمودـ د/ أسماء مصطفى_ د/ عاطف سالم<smiles>C=C</smiles> 


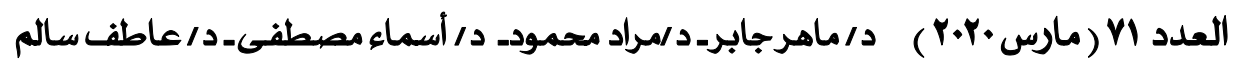

\section{المبحث الأول: - ماهية الأجل}

الأصل أن يكون الالتزام منجزاً وبسيطاً إلا إذا دخلت عليه أوصـاف تجعله يخرج

عن هذا الوصف، ويعد الأجل من الأوصـاف التي ترد على استحقاق الالتزام بحيث يصبح الالتزام غير منجز فيترتب على الأجل إمـا إرجاء الالتزام او إنقضاؤه. ولذلك سنقسم هذا المبحث إلى مطلبين؛ المطلب الاول نتحدث فيه عن تعريف الأجل وأنواعه، أما المطلب الثاني فسوف نتناول فيه شروط الأجل.

\section{المطاب الأول: تعريف الأجل وأنواعه}

ذكرنا سـابقا أن الأجل هو وصف يرد على الالتزام من ناحية استحقاقه بحيث

يكون أمر استحقاقه معلقاً على تحقق أو تخلف هذا الأجل سواء كـان هذا الأجل تاريخًاً معينًا أم واقعة مادية معينة. فمن يقوم بشر اء منزل مثثلا على أن يقوم بسداد قيمته بعد شهر من تاريخ البيع يكون التزامه موصوفاً مع البائع بحيث لا يتمكن بائع المنزل من

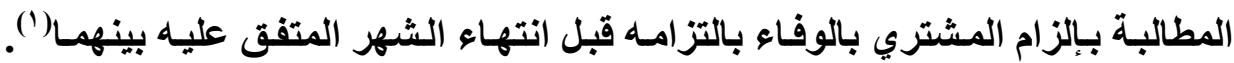

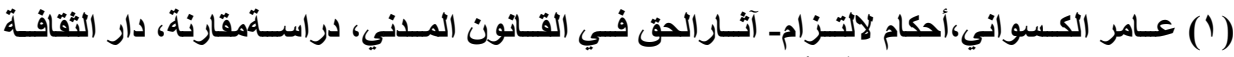

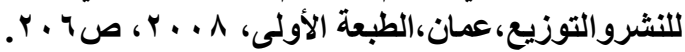
ياسين الجبوري، المبسوط في شرح القانون المدني،دار الثقافة للنشر والتوزيع، عمان، ب . . ب،

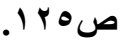




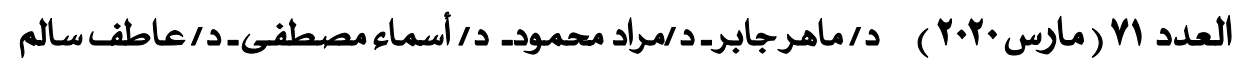

لذلك ابتداءً سوف نحاول في هذا المطلب التعرف على المقصود بالأجل في الفرع الأول، وأما الفرع الثاني فسوف نتطرق فيه إلى أنواع الأجل.

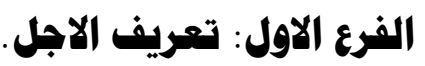

يعرف الفقه الاسلامي الأجل بأنه "المدة المعلومة من الزمن والتي توجب تأجيل

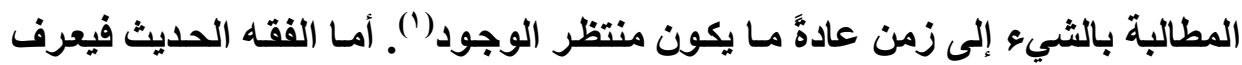

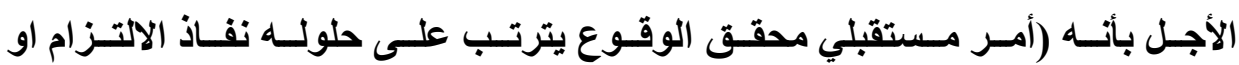

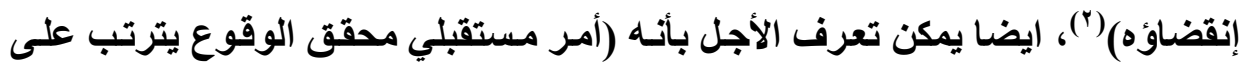

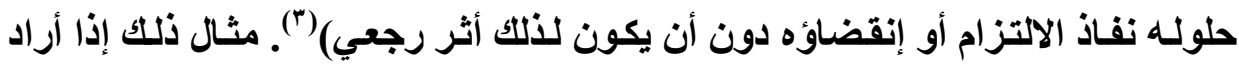
شخص تأجير بيته لمدة سنة تنتهي في اخر ديسمبر من العام الحسالي، فإن حلول هذا التاريخ يترتب عليه إنقضاء عقد الايجار ويسمح للمؤجر التحلل من هذا العقد. أمسا بخصوص القانون المدني الاردنـي فلم يتطرق صراحة لتعريف الأجل كمـا تعامل في تنظيمه القانوني للشرط الذي أورد له تعريفأ قانونياً صريحاً قبل البدء بتنظيم أحكامسه. ومـع ذلك فقد عرف المشرع الأجل ضـمناً عندما نص على إمكانيـة تعليق

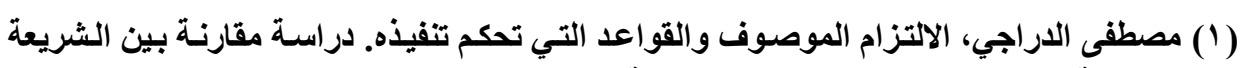

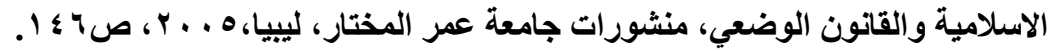

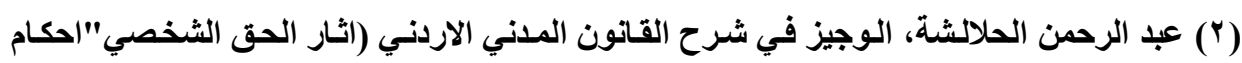

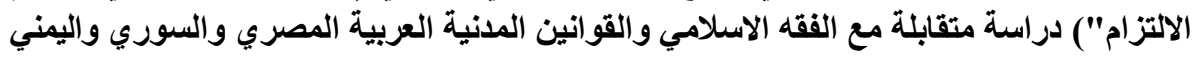

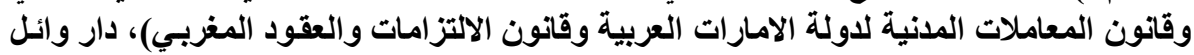

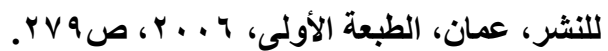

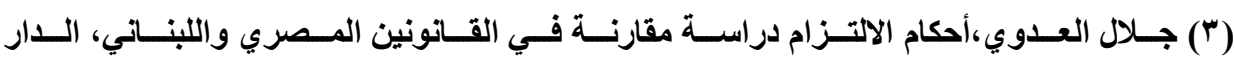

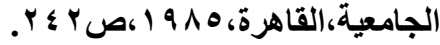

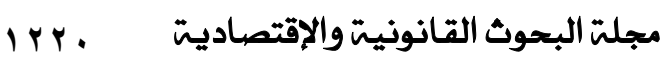




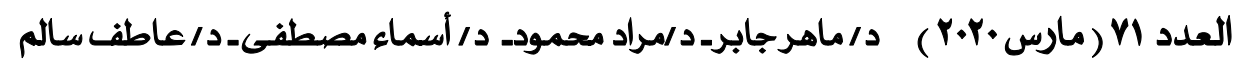

الالتزام على أجل معين حيث نصت المادة r ـ ؛ على أنه "يحوز اضافة التصرف إلى إنى

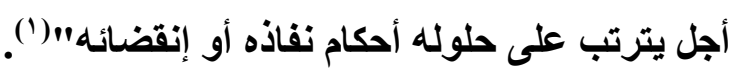

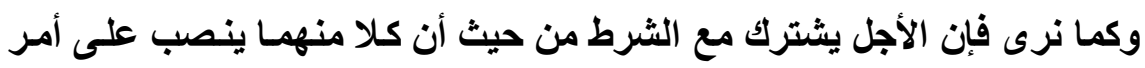

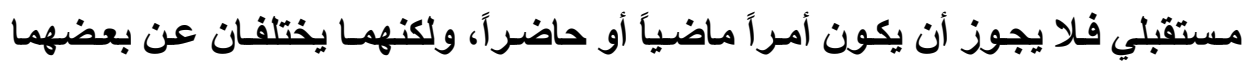
اختلافاً جوهرياً من حيث أن الثرط يعتبر أمراً غير محقق الوقوع فقد يتحقق وقد لا لافيران

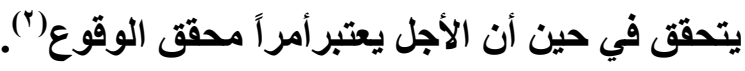

\section{الفرع الثاني: أنواع الأجل}

من خلال استعراض نصوص القانون المدني الأردني والقوانين المقارنة يتبين

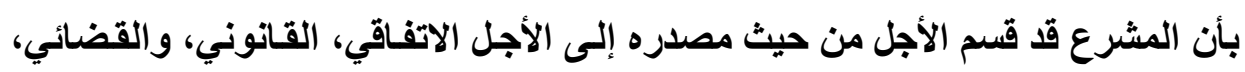

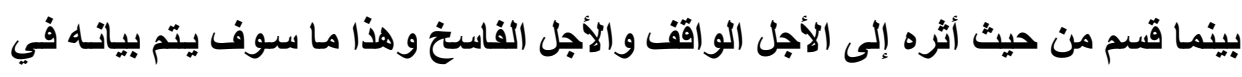

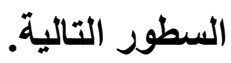

$$
\text { أولا: أنواع الاجل من حيث مصدره وتقسم إلى: }
$$

ا ـ قد يكون مصدر الأجل اتفاق طرفي الالتزام أي أن مصدره إرادة المتعاقدين وهو

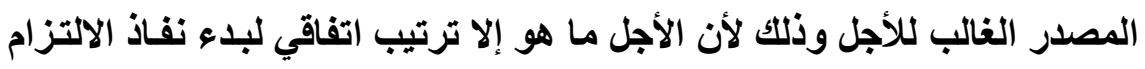

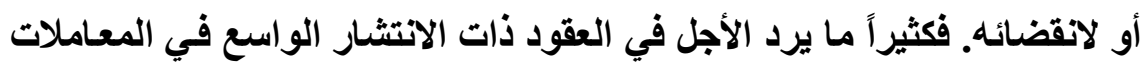

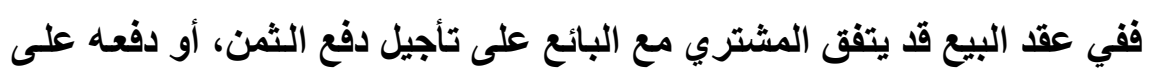

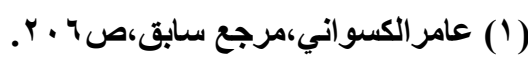

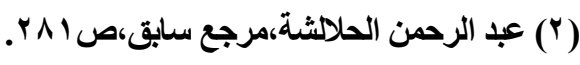




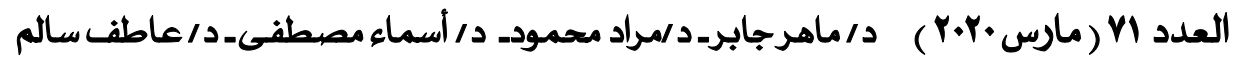

أقساط معينة في آجـال محدة فيكون الأجل واقفاً متعدد التوقيت، أو أن يعين المؤجر والمستأجر تاريخ انتهاء عقد الإيجار.

في هذه النواع من الأجل قد يكون الاتفاق على الأجل صريحاً أو ضمنياً يمكن استتباطه من ظروف التعاقد ومن طبيعة العقد؛ فمثلاً عندما يتعهد مقاول بإنشاء

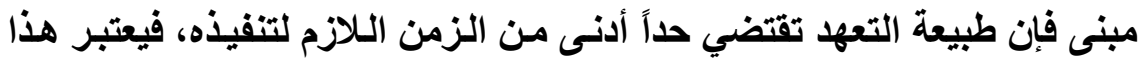

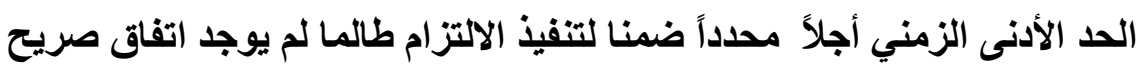
على تحديد أجل اخر ('). أما في حالة عدم تحديد الأجل صراحة ولم يكن ممكنا استتتاجه ضمناً فيعد الالتزام منجزاً ويتعين تنفيذه فوراً ("). r. وقد يكون مصدر الأجل القانون، فقل يتلخل القانون أحيانا في تحديد الأجل كما

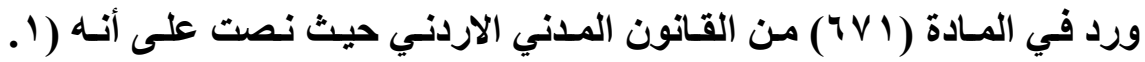
يجب ان تكون مدة الاجارة معلومة ولا يجوز أن تتجاوز ثلاثين عامـا فإذا عقدت

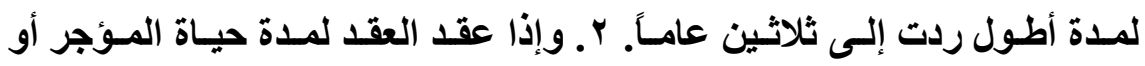

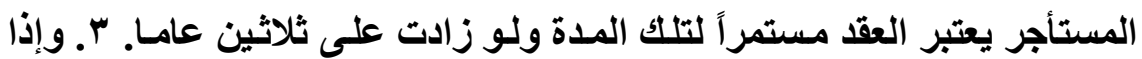
تضمن العقد أنه يبقى ما بقي المستأجر يدفع الاجرة فيعتبر انه قد عقد لمدة حياة

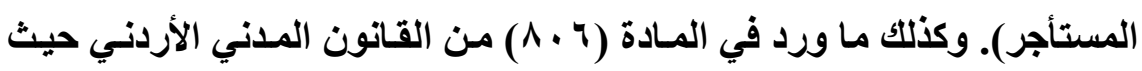
نصت على أنسه (1 ـ يجوز أن يكون عقد العمل لمدة محدودة أو غير محدودة ولعمل معين. r. ولا يجوز أن تتجاوز مدته خمس سنوات فاذا عقد لمدة أطول ردت إلى خمس). كذلك ما قضى به المشرع فيما يخص حقّ الانتفاع حين جعله فئه

(1) عبدالقادر الفار،أحكام الالتزام: آثـار الحقى في القـانون الأردنسي، دار الثقافة للنشر والتوزيع،

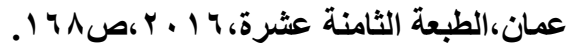

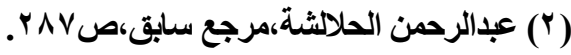

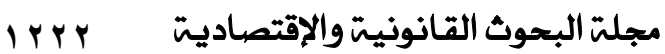


العدد ال (مارس_r.r.r) د/ماهرجابر-د/مراد محمودـ د/ أسماء مصطفى_ د/ عاطف سالم

ينقضي بوفاة المنتفع فهو حق مقرر لحياة المنتفع. كمـا يعد حق الانتفـاع وحق

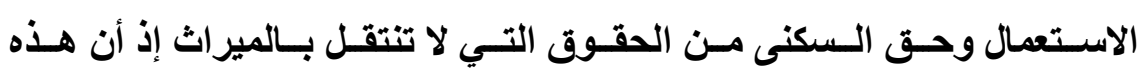
الحقوق تتتهي بموت أصحابها حتى لو تحقق الموت قبل انقضاء الإجل المعين لاحق (')

r. وأخيراً قـ يكون مصدره قضائيا وهو الأجل الأي يمنحه القاضسي للمدين المعسر

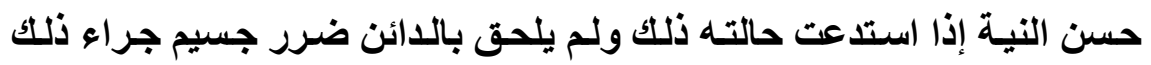

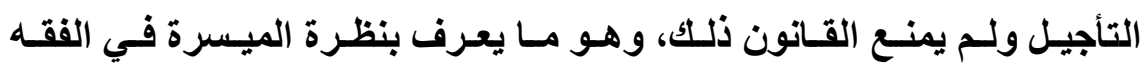
الاسلامي. فهو إرجاء لتنفيذ التزام يأمر به القضاء رغم حلول أجل الوفاء مراعاة لحالة المدين وظروفه، حيث يمنح القاضي المدين المعسر نظرة الميسرة، استناداً إلـى السلطة الإسـثنائية التي منــه إياهـا القـانون بإضـافة تنفيذ الالتزام إلى حين يستطيع المدين ذلك، وعلى القاضي عند اللزوم أن يحدد ميعاداً مناسباً لحلول الأجل

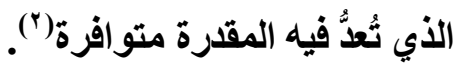
ثانيا: أنواع الأجل من حيث الاثر ويقسم الى نوعان وهما: ا. الأجل الواقف هو الأي يتوقف على حدوثـه نفـاذ الالتزام، أي أن نفـاذ الالتزام يكون متوقفاً على أمر مستقبل محقق الوقوع بمعنى أن الأئن لا يستطيع مطالبة المدين بأداء الدين قبل حلول هذا التاريخ، فإذا التزم المدين بوفاء الدين في تاريخ معين، فالتزامـه يكون التزامساً مربوطاً بأجل واقف. إن الالتزام في حالة الأجل الواقف موجود ومستكمل لعناصره وأركانهـ إلا أن نفـاذه أضيف إلى أجل 


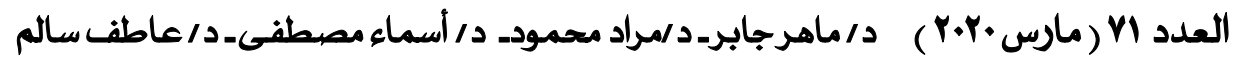

فهو حق غير نافذ، فلا يمكن المطالبة بتنفيذه في الحسال، وهذا مـانصت عليه المادة (r • ؛) من القانون المدني الاردني بأنه (يجوز اضافة التصرف إلى أجل

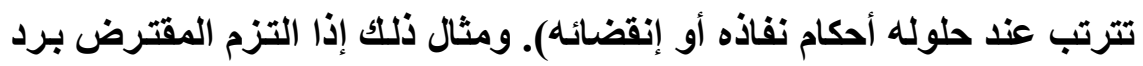

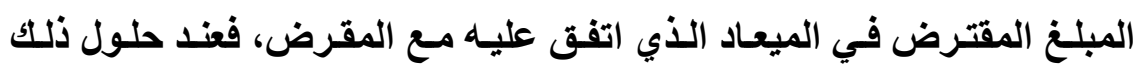

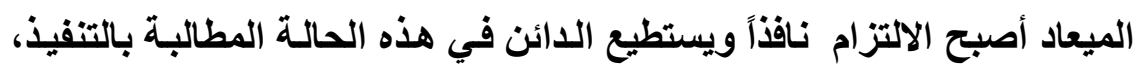

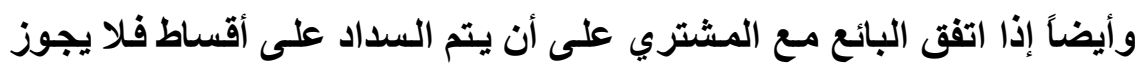
للبائع المطالبة بأداء أي قسط من الأقساط قبل حول أجل الاستحقاق. ويترتب على اعتبار الحق المقترن بأجل واقف أنه حق موجود ولذلكك فيمكن

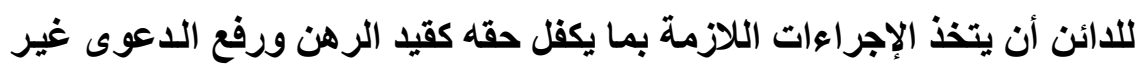

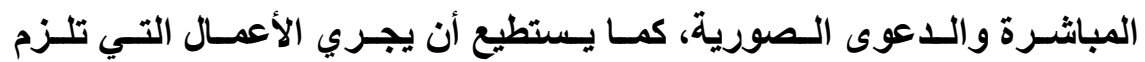
للمحافظة على حقه من التلف، وهذا الحق ينتقل إلى الغير بالتصرف و الميراث.

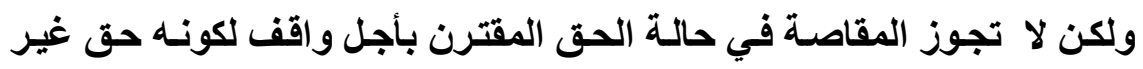
مستحق الأداء، ولا يجوز لصاحبه أن يتمكك فيه بالحق في الحبس، فضلاً عن العن

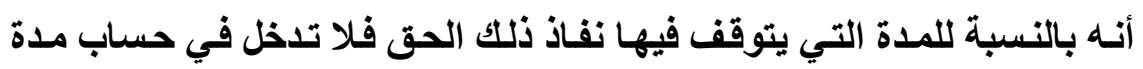

$$
\text { سقوطه بالتقادم (1). }
$$

r. الأجل الفاسخ هو الذي يترتب على حدوثه إنقضاء الالتزام، فإنقضاء الالتزام

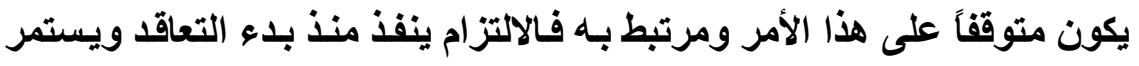

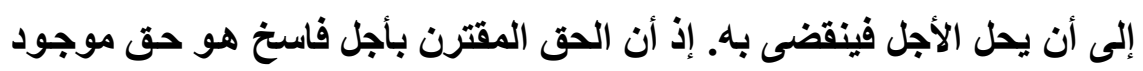
ونافذ لكنه مؤكد الزوال. فإذا أجر زيد داره لمدة سنتين فالتزاماته كمؤجر تكون التاني مربوطة بأجل فاسخ بمعنى أنها تنقضي بانتهاء السنة الثانية من مدة الايجار

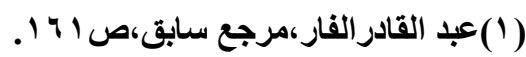




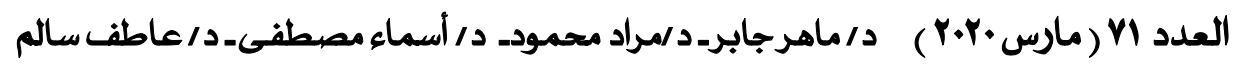

ويستطيع زيد التحلل منها باتتهاء هذه السنة. وأيضاً كما في حالة التزام شركة

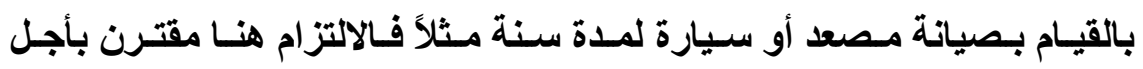

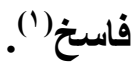

وبما أن الحق المقترن بأجل فاستخ هو حق موجود ونافذ ولكنـه مؤكد الزوال

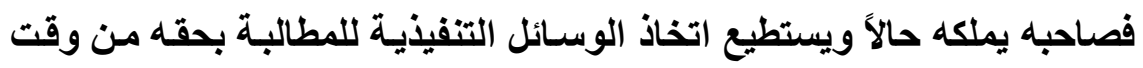

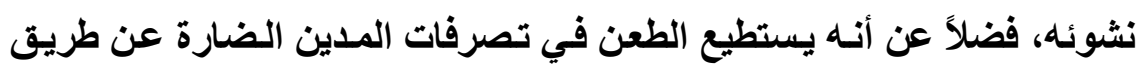

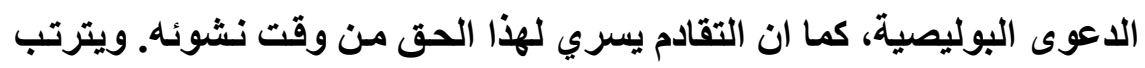
على اعتبار الحق المقترن بأجل فاسـخ أن جميع تصرفات صـاحب الحق تكون مقيدة بحدود هذا الحق، فيكون انتقال الحق إلى الخلف العام أو الخلف الخـاص

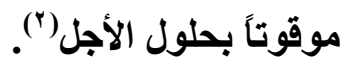

\section{المطاب الثاني: شروط صحة الاجل}

وفقاً لأحكام القانون المدني الاردني وبالتوافق مـع مـارجح عليـه الرأي الفقهي فإنه ينبغي توافر أمرين لاعتبار الأجل صحيحاً ومرتباً لآثاره القانونية، وهذين الأين الأمرين

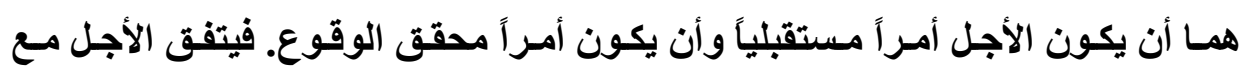
الثرط في أنه يتوجب أن يكون كلاً منهما معلقاً على واقعة أو أمر مستقبلي. إلا أنهما يختلفان في أن الأجل يتوجب أن يكون محقق الوقوع بينمـا يتوجب في الشرط ليكون

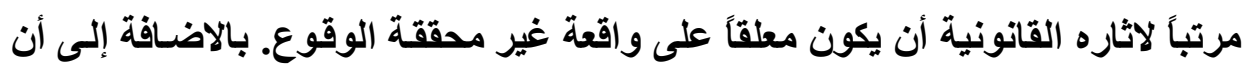

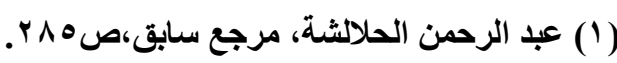

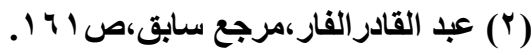


العدد ال (مارس_r.r.r) د/ماهرجابر-د/مراد محمودـ د/ أسماء مصطفى_ د/ عاطف سالم

الثرط قد يعلق على واقعة قد تكون مستحيلة وقد تكون غير مستحيلة وهو ما لـ يمكن تصوره في الأجل الذي يرتبط دومـاً بأجل لا يتصور أن يكون مستحيلاً حيث أنـه دومـاً

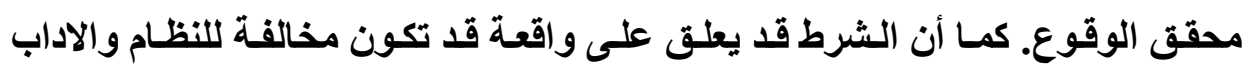
العامة وقد لا تكون، وهو ايضاً مـا لا يمكن تصوره بخصوص الأجل الذي يكون دومـاً

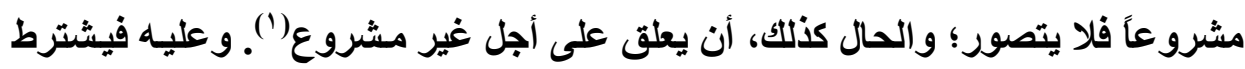
في الأجل ليكون مرتباً لآثاره القانونية ما يلي: ولئ أولاً: يجب أن يكون الأجل أمراً مستقبلاً:

إن الأجل كمـا ذكرنـا سـابقاً هو وصف يرد على الالتزام ولا يصح إلا أن يكون مستقبلاً، أي أن يكون متعلقا بواقعة لم تحصل ولم تتحقق بعد ومن الممكن وقوعها في ولي المستقبل، فلا يمكن أن يتعلق الأجل بأمر في الماضسي أو الحاضر. فهو مئو ميعاد مستقبلي

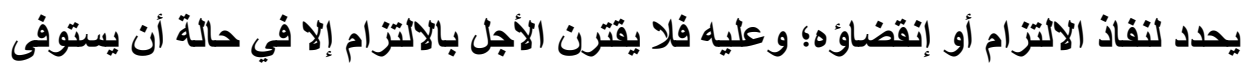
الالتزام جميع عناصر تكوينه فيأتي الأجل بعدها كعنصر اضافي على الالتزام(؟). ويما أن الأجل لا يجوز أن يكون أمراً ماضياً أو حاضراً حتى لو كـان المتعاقدان يجهلان وقت التعاقد أن الأجل الذ حدداه هو أجل قد حل، كمـا لو حدد شخص قدوم أول أول قافلة من الحجيج أجلاً لنفاذ التزامه وكان يجهل أن القافلة قد قدمت فعلاً قبل أن يلتزم.

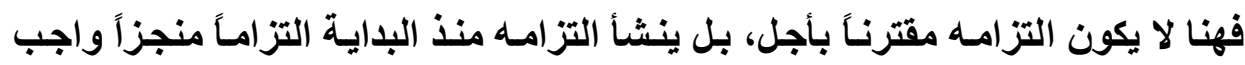
الأداء في الحال(") كما يمكن أن يكون الأجل متعلقاً بواقعة مستقبلية لا يعرف بالتحديد

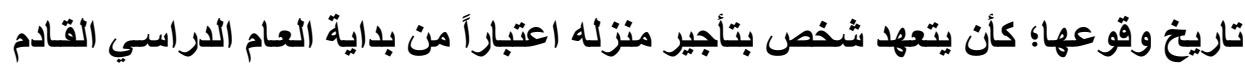
وكان موعد بلاية العام الدراسي الجديد لم يحدد بعد.

$$
\begin{aligned}
& \text { (1) المرجع السابق،ص170 } 17 .
\end{aligned}
$$

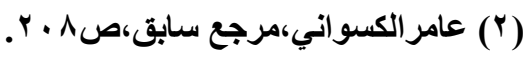

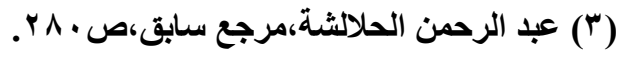


العدد ال (مارس_r.r.r) د/ماهرجابر-د/مراد محمودـ د/ أسماء مصطفى_ د/ عاطف سالم

ثناتياً: يجب أن يكون الأجل أمراً محقق الوقوع:

وهذا ما يميز الأجل عن الشرط، إذ أن الأجل يكون محقق الوقوع في المستقبل

حتى لو لم يعرف تاريخ وقوعه بالتحديد سواء كـان ذلك التحديد مرتبط بواقعة معينة كالوفاة مثُلًا أو بتـاريخ معين. وغالبًا مـا يكون ميعاد وقوع الأجل معلومـاً منذ نشوء

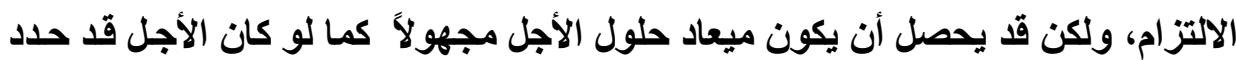
بموت شخص فإن الموت يعتبر أمرا لا يعرف الوقت الذي سوف يقع فيه، ولكن وقوعه يعتبر أمراً محتومـاً؛ فلو تعهد شخص بالإشراف على تعليم فتى بدءء من تـاريخ وفاة والده، فالتزام المتعهد هنا معلق على أجل هو موت والد الفتى، وموت الوالد أمر محقى الوقوع، لكن لا يمكن تعديد توقيته مسبقاً. وعليه فيجب أن يكون الأجل الذي يضاف إلى الالتزام أن يكون يكون مؤكد الوقوع او حتمي الوقوع سواء كان تـاريخ وقوعه معروفاً او غير معروف. إذ يعتبر

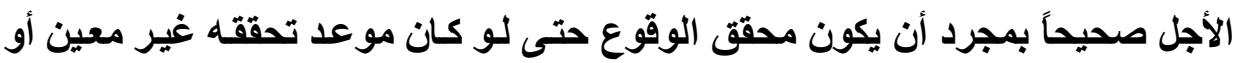
من الصعب تعيينه كواقعة الموت مثلاًَ'(') الذي يعتبر أمراً محقق الوقوع إلا أن تـاريخ وقوعه غير معروف، فعلى سبيل المثال في عقود التأمين على الحياة تلتزم شـركة التأمين بدفع مبلغ التأمين عند موت المؤمن على حياتها وهو التزام مضاف إلى إجل غير معين. كما أن التزام زيل بلدفع راتب لعمر مدى حياة عمر يكون فيه إبراء ذمـة زيلـ وتحلله من التزامه بدفع الراتب لعمر معلقاً على أجل غير معين وهو وفاة صاحب الحق

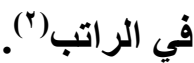

(1 ) عامر الكسو اني،مرجع سابق،ص 9 ـ r.

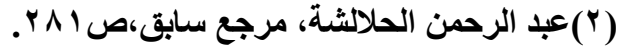


العدد ال (مارس_r.r.r) د/ماهرجابر-د/مراد محمودـ د/ أسماء مصطفى_ د/ عاطف سالم<smiles>C=C</smiles> 


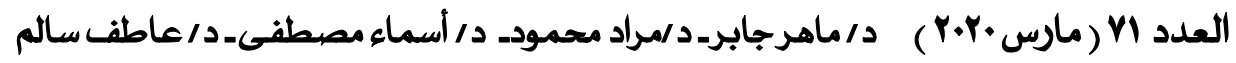

\section{المبحث الثاني: سلطة القاضي في تعديل الاجل}

الأصل أن على المدين أن يفي بالتزامه بمجرد ترتبه في ذمته أو حلول أجلهه. إلا

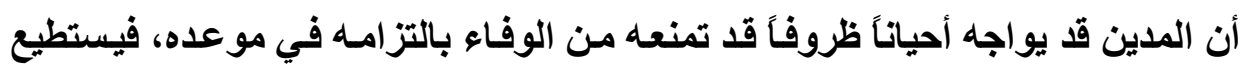

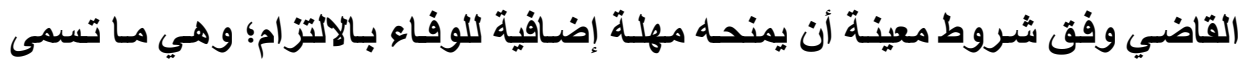
بالمهلة القضائية أو نظرة الميسرة. وتختلف أحكام المهلة القضائية وفق طبيعة الالتزام إن كان مدنياً أو تجارياً؛ إذ أن صلاحيات القاضي في إعطاء مهلة إضافية للمدين للوفاء

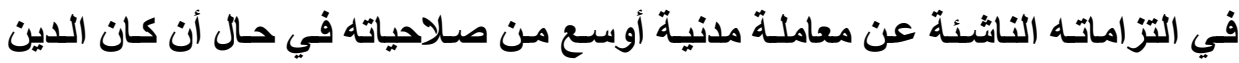

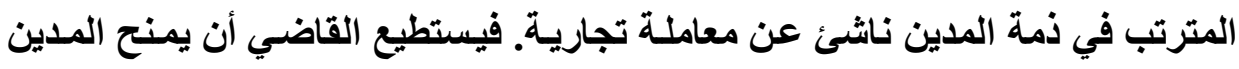
مهلة للوفاء بدينه الذي حل أجله فينظه إلى أجل أو أجال معينة ينفة فيها التزامه وذلك فئك التهائ متى توافرت الشروط التي اشترطها القانون. والعبرة من تساهل المشرع مع المدين

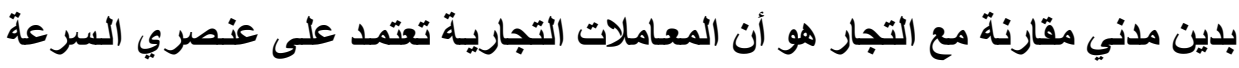
والإنتمان؛ فالمعاملات التجارية كثيرة في حياة التاجر ومتشابكة ايضاً فقد يكون دائناً

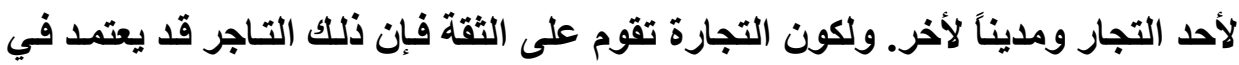

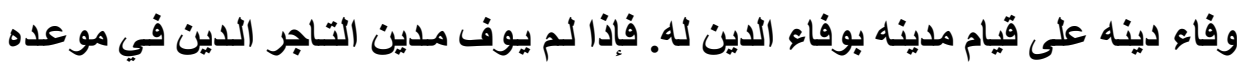

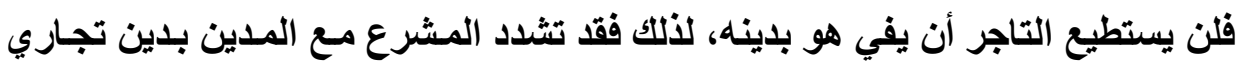
ومنع القاضي من أن يمنحه أجلا لوفاء الاين إلا في حالات استثنائية معينة.

إن القاضي عندما منحه القانون سلطة تعديل الاجل الذي اتفق عليه المتعاقدين

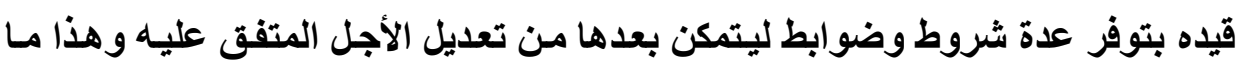

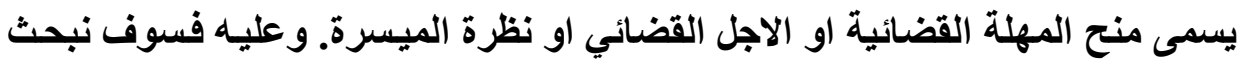

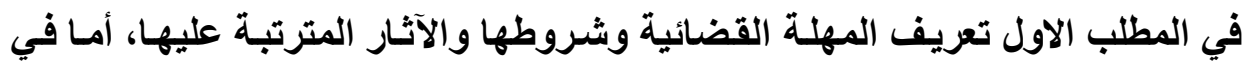




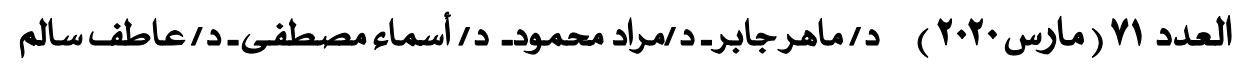

المطلـب الثـاني فـسوف نتـــاول فيـهـ ســلطة القاضــي فـي تعـديل الأجـل وإعطـاء المهلة القضائية ومـدى رقابـة محكمة التمييز على تلك السلطة التقديريـة الممنوحة

للقاضي.

\section{الاملب الأول: المهلة القضائية (نظرة الميسرة)}

يمنح القاضي المدين اجلا في حالة اذا استدعت حالته ذلك ولم يلحق بالائن ضرر جسيم نتيجة للتأجيل ولا يوجد نص قانوني يمنع ذلك. ويسمى الاجل القضائي في

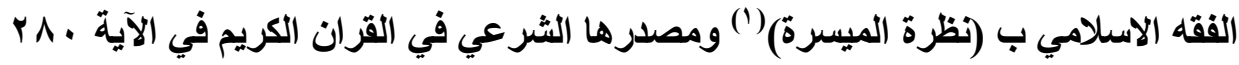

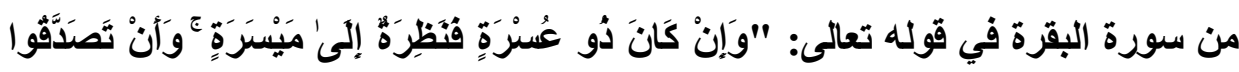

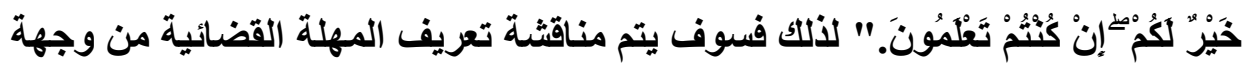
نظرالققه الاسلامي والفقه القانوني الوضعي - تحديداً من خلال استقراء نصوص الوس القانون المدني الأردني والقوانين المقارنة في الفرع الأول. اما الفرع الثاني فسوف يتم تناول الشرائط القانونية لمنح المهلة القضائية. امـا في الفرع الثالث فسوف يتم البحث في الاثار المترتبة على منح القاضي للمدين مهلة قضائية.

\section{الفرع الاول: تعريف المهلة القضائية.}

يعرف الاجل القضائي في الفقه الاسلامي بأنه "مهلة استثنائية يمنحها القاضي

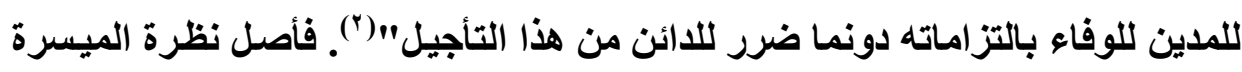

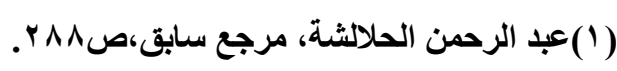

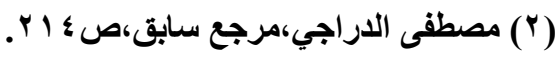

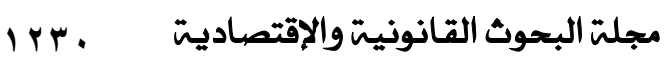




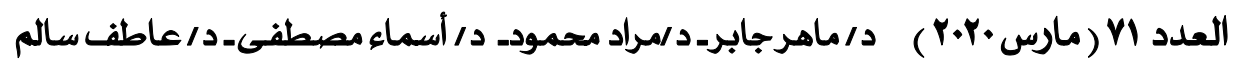

هـو الشريعة الإسـلامية التي جمعت بـين المبـادئ الروحيـة وبـين معالجـة الأوضـاع الانيوية، فقامت بوضع أحكام مفصلة للالتزامات المؤجلة على وجها لا يـاع فرصـة لكل من المدين أو الدائن ليضرّ أي منهما بها الاخر. فنظرة الميسرة في الفقه الإسلامي تقوم على إعطاء القاضي صلاحية إنظار المدين المعسر إلى ميسرة في العقود التي حلّ أجل وفائها، حيث أنه متى أصبح المدين المعر موسرًا كـان ملزمـا بالوفاء. إن الأجل الذي الذي يمنحه القاضي في هذه الحالة ينظوي على حقيقتين أساسيتين يتمثلان أولاً بأن الأجل الممنوح يمنح تقديراً لظروف المدين المعسر هذا من جهة، وثانيـاً أن العقد في الأصل

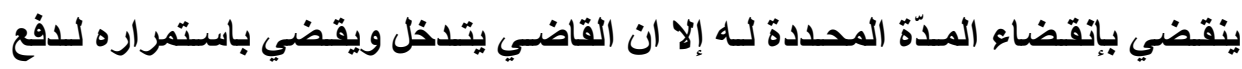
الضرر الأي قـ يلحق بالمدين.

لـلكك فقد اتفقت المـاهب الإسـلامية الأربعة على مـنح المـدين المعسر نظرة الميسرة، إذا ما ثبت إعساره بالبينة، فيعتبر إنظار المدين المعر في هذه الحالة تعديلا للعقد. كما اتفقت على أن نظرة الميسرة عامّة؛ أي أنها لا تتعلق بدين دون الآخر فبإذا ما وجلت حالة الإعسار فعلى القاضي الحكم بها' '). كما تعرف نظرة الميسرة بأنها "مهلة التفيذ أو الأجل القضائي التي يمنحها القاضي للمدين عاثر الحظ حسن النية إذا استدعت حالته ذلك ولم يلحق الدائن من ذلتك ضرر جسيم، وذلك حتى ينفذ التزامسه ويتوقى الفسخ() أي أن المهلة القضائية أجل ( (1) طرطاق نورية، نظرة الميسرة في القانون المدني الجزائري، رسـالة ماجستير، جامعة الجزائر،

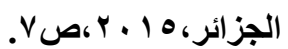

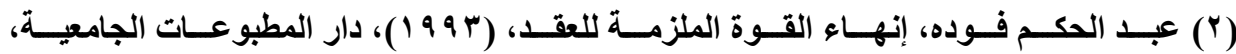

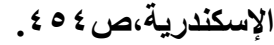




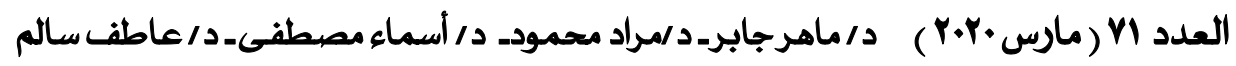

مصدره القضاء وأساسه القانون الأي يجيز للقاضي أن يمنح المدين حسن النية أجلا أو آجالا معقولة للوفاء بلينه، ما دام لم يلحق الدائن من ذلك ضرر جسيم" (1")

مـن خـلال ماسـبق يمكنتـا تعريـف المهلـة القضائية بأنهـا المهلـة التي يمنحهـا القاضي للمدين الذي يمر بظروف صعبة تجعله غير قادر على الوفاء في الميعاد المحدد شريطة عدم لحاق أي ضرر جسيم بالدائن. لكن من خلال استعراضنا لنصوص القانون المدني الاردني - وتحديداً المواد

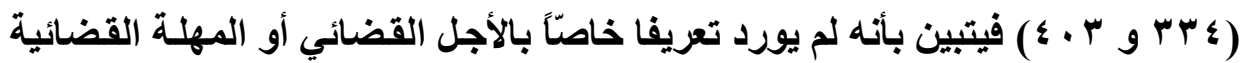
أو ما يعرف بنظرة الميسرة، وإنما وضع نصوصاً قانونية تتعلق بها وتتضمن الشروط التي يجب توافرها ليمنح القاضي نظرة الميسرة. لقد نصت المادة (ع سץ) من القانون المدني الأردني على أنـه ( ـ يجب أن يتم الوفاء فوراً بمجرد ترتب الالتزام نهائياً في ذمة المدين مالم يوجد اتفاق أو نص يقضي بغير ذلك. Y. على أنه يجوز للمحكمة في حالات استثنائية إذا لم يمنعها نص في القانون أن تنظر المدين إلى أجل معقول أو اجال ينفذ فيها التزامـه اذا استدعت حالته ذلتك ولم يلحق الدائن من هذا التأجيل ضرر جسيم). أمسا المـادة (ب + ؛ ) من القانون ذاته فقد

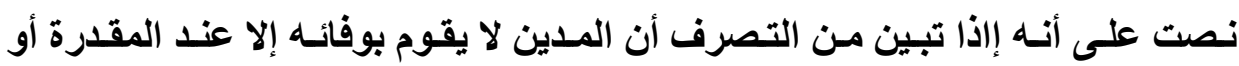
الميسرة حـدت المحكمـة أجلـل الوفـاء مراعيـة مـوارد المـدين الحاليـة والمسـتقبلية ومقتضية منه عناية الحريص على الوفاء بالتز (مه).

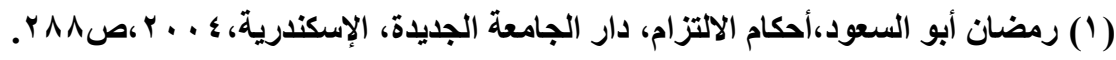

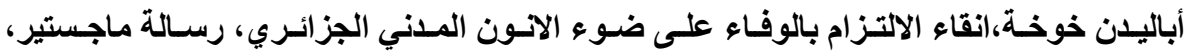

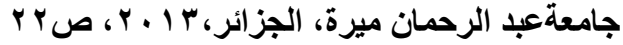

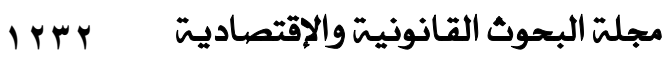




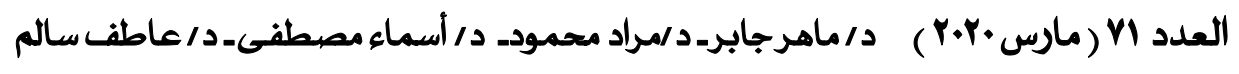

من خـلال تلك النصوص فإنـه يتبين بـأن نظرة الميسرة تمتـاز بالعموميـة في التطبيق سواء من حيث محل الالتزام أو مصدر الالتزام. فمن حيث محل الالتزام تمنح نظرة الميسرة في كل الالتزامات بصرف النظر عن محلها سواء كان محل الالتزام نقوداً أو تسليم شيء أو غيره، فهي ليست محددة في الديون المتمثلة في المبالغ المالية فقط، بل يمكن أن تمنح مهما كان نوع الالتزام الذي يقع على المدين، حيث يمكن أن يكون الالتزام إعطاء شيء أو القيـام بعدل أو حتى الامتتـاع عن عمل، ومثـال ذلك: الالتزام بمغادرة بيت السكن المشفول بطريقة قانونية. وأمـا من حيث مصدر الالتزام فتمنح نظرة الميسرة في جميع الالتزامات سواء كان مصدر الالتزام ناشئًاً عن إرادة منفردة أو

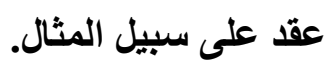

\section{الفرع الثاني:}

\section{شروط هنح المهلة القضائية والاثار القانونية المترتبة على هنمها.}

لقد حدد المشرع الأردني وفي أكثر من موضع على عدد من الشرائط القانونية

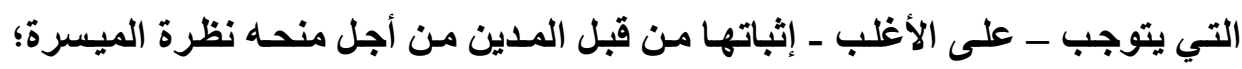

$$
\text { وتتمثل تلك الثرائط بما يلي: لتوجي: }
$$

أولاً: أن لا يوجد نص قـانوني يحول دون منـح المهلة القضائية. فقد قيد المشرع

الأردني صلاحية القاضي في منح المهلة القضائية في مواضع متعددة؛ ومثال

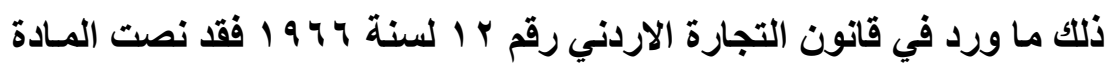

(1/07) على عدم جـواز مـنح نظرة الميسرة للمـدين بـدين تجـاري إلا في

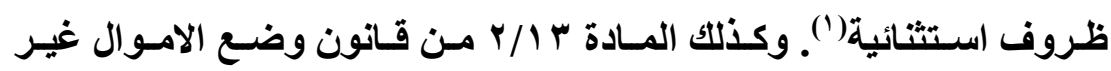

(1) (1) القادر الفار،مرجع سابق،ص 9 ؛ . 


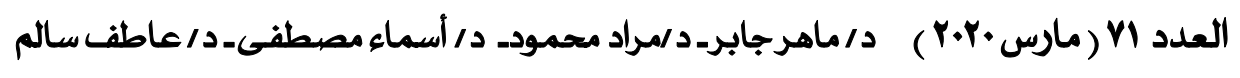

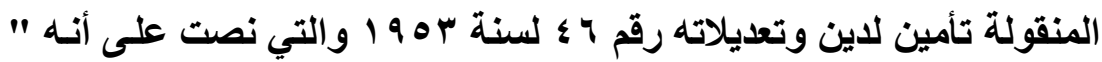
إذا طلب المدين خـلال المدة المبينة في الفقرة السابقة من رئيس المحكمة البدائية الواقع المال الموضوع تأميناً للاين ضمن منطقتها إرجاء البيع فإنه لا يجوز لله أن يجيب المدين إلى طلبه لمدة لا تزيـ على شهرين ولمرة واحدة فقط إذا اقتتع: أ. بأن لاى المدين مجالاً واسعاً لتسديد الدين المستحق عليه إذا أعطي مهلة. ب. بأن بيع مال المدين قد يسبب له ضـائقة لا داعي لها مراعياً في ذلك جميع ظروف الحال واحتياجات الدائن الخاصة).

ثانياً: أن تكون حالة المدين تستدعي منحسه نظرة الميسرة. وهنـا يمكنــا القول بـأن منسح القاضـي مهلة الوفـاء للمدين يتطلب من القاضسي التأكد من أن المـدين حسن النية؛ فأساس العلاقات التعاقدية نابع من مبأ حسن النية الذي ينطوي على التعامل بصدق واستقامة وشرف مع الغير بصورة تبقي ممارسـة الحق مأق ضمن الغاية المفيدة التي أنشئ من أجلها واتفق أطراف العقد على تحقيقها. والأصل أن حسن النية لاى المدين مفترض ما لم يثبت الدائن أن مدينه كـان

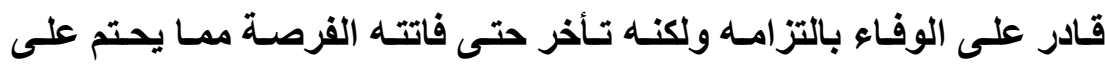
القاضي عدم منحه نظرة الميسرة. ايضاً ينبغي على القاضي التيقن من أن المدين سيء الحظ حتى يمنحه المهلة في الوفاء، أي أن المدين يمر بأزمـة طارئـة ومؤقتـة يمكن تجاوز هـا في حسال منحه أجلاً اضافياً من قبل القاضي للوفاء بالتزامه الذي يستطيع بعد التأكد من ظروف المدين الاقتصادية منحه هذا الأجل مع ضرورة الأخذ بالاعتبار التأكد

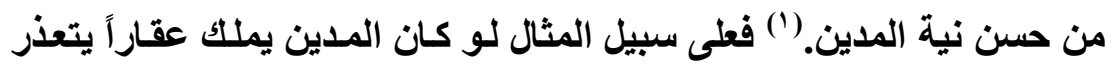




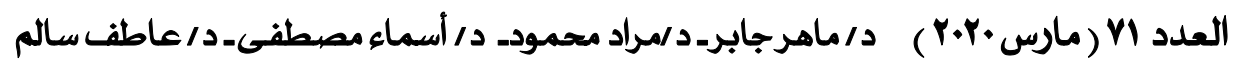

بيعه في الحال فيستطيع القاضي منحه أجلاً إضـافياً ليكون لايـه الوقت الـلازم

لبيع العقار والوفاء بالتز امه.

ثالثًا: ألا يلحق الدائن جراء منح المدين نظرة الميسرة ضرر جسيم. فعلى القاضي

أن يوازن ما بين مصالح الدائن ومصالح المدين، فقد يعول الدائن على قضاء التزاماته بوفاء المدين بالتزامه مما يلحق ضرراً جسيماً بالدائن؛ وعليه فـلا يجوز للقاضي في هذه الحالة أن يمنح للمدين مهلة للوفاء لأن مصلحة الدائن هنا أولى بالرعاية، ولن يكون من العدل مساعدة المدين عن طريق التسبب بأضرار بليغة للائن.

رابعاً: يشترط في الأجل الممنوح للمدين أن تكون مدته معقولـة ومناسبة. فلا يجوز للقاضي أن يمنح المدين مدة طويلة للوفاء بالتزامه، بل يفترض أن تكون مدة معقولة وكافية لتحقيق الهرف من منحها وهو مساعدة المدين بحيث يتمكن من الوفاء بالتزامسه(') وفي هذا المقام نأخذ على المشرع الأردنسي بأنـه لـ لم يحدد في القانون المدني الاردنسي حداً أدنى أو أقصى لهذه المهلة القضائية

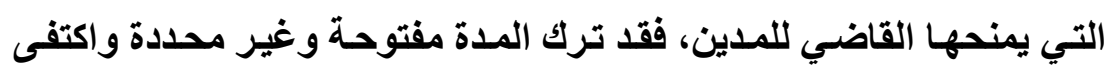
بالنص في المادة (ه r بr) من القانون المدني الاردني على (...أن تنظر المدين الى اجل معقول...).

متى تحققت تلك الشرائط القانونيـة مجتمعة والتي قيــ المشرع مـن خلالهـا صلاحيات القاضي في منح المهلة القضائية مجتمعة جاز للقاضسي منح المدين مهلة وفاء إضـافية تتناسب مـع أوضـاعه شريطة عدم لحساق أي ضرر جسيم يصيب الدائن

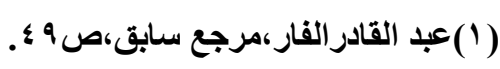




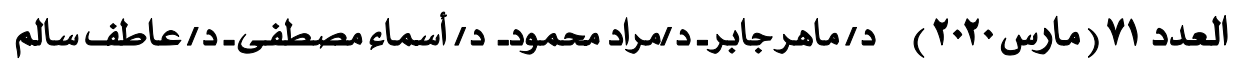

نتيجة هذا الأجل بنفس الوقت. وعليه متى تدخل القاضي ومنح نظرة الميسرة للمدين فِإن قراره هذا يرتب عدداً مـن الاثـار القانونيـة تمثثل ابتـاءعً بوقف إجراعات التنفيذ والدعوى التي أقامها الدائن بحق المدين. كمـا أن الدين يبقى مستحق الأداء وبجميع الالتزامات المترتبة عليه فيبقى الإعذار بكامل اثثاره وتنتقل تبعة الهلاك إلى المدين الذي لم يقم بتسليم محل الالتزام في الوقت المحدد لـه. ايضاً فبان قرار منح الأجل القضائي للمدين يبقي من حق الدائن اتخـاذ كافة الاجراءات اللازمـة للمحافظة على حقه كرفع الاعوى غير المباشرة أو الدعوى البوليصية وذلتك بوصف ذلتك الدين ديناً حسال الأداء فالمهلة التي منحها القاضي لا تنشئ ديناً جديداً بأجل جديد وإنمـا تعطي مهلة للمدين للوفاء بذلك الدين الأي حل أجل الوفاء به. لذلك؛ وحيث أن من شروط إجراء المقاصة القانونية أن يكون الدين حال الأداء فإن منح المهلة القضائية لا يمنـع الدائن أو المدين من المطالبة بإحراء المقاصـة القانونية متى توافرت شرائط إعمالها. ايضاً لا يترتب على منح المهلة القضائية وقف فوائد التأخير المستحقة على الدين على أسـاس أن الفوائد القانونية تترتب من التاريخ الذي طلب فيه المدين منحه المهلة الإضافية للوفاء.

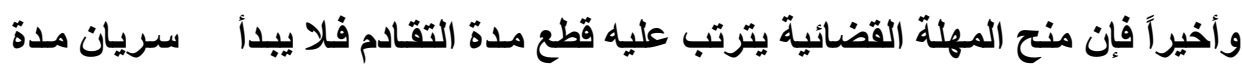
التقـادم على الحقى قبل إنقضاء المهلـة القضائية الممنوحسة للمـدين للوفـاء بـالالتزام

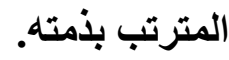




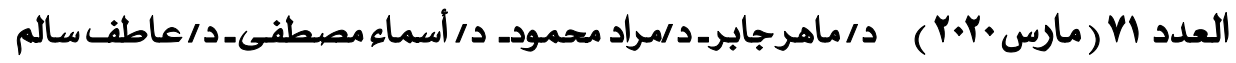

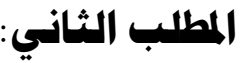 \\ هدى سلطة القاضي التقديرية في تعديل الأجل \\ ورقابة همكمة التمييز عليه}

لقد نصت القواعد العامـة في كافة التشريعات والاتفاقيات الدولية على قاعدة أساية تتمثل في أن العقد شريعة المتعاقدين وع ذلك فقد تلذلل المشرع وأعطى قاضي

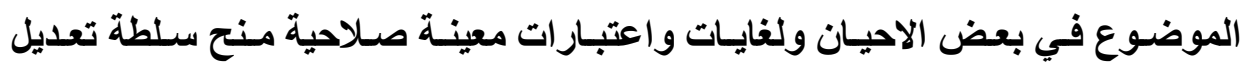
الأجل. إن هذا ألأجل يعد استثناء على القاعدة العامة بحيث قيد من إرادة أدراف النزاع

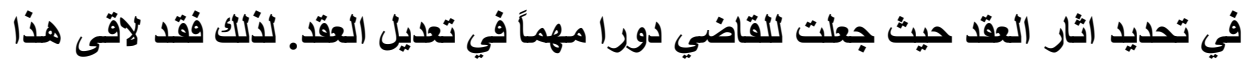
التوجه نقاً من جانب بعض فقهاء القانون الوضعي على أساس أن مثل تلتك الصلاحيات المنوحة للقاضي تثكل اعتداءً على حرية التعاقد وانتقاصاً منها كما أنها تتؤدي إلى عدم التهاء استقرار المعاملات المدنية. ولكن أنصار منح مثل تلكت الصلاحيات للقاضي - ونذهب مع هذا الاتجاه - يرون في ذلك رعاية للمصالح وتحقيقًا للعدالة. فتلك السلطة التقديرية

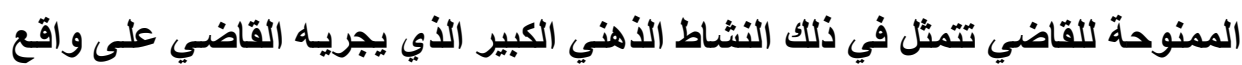

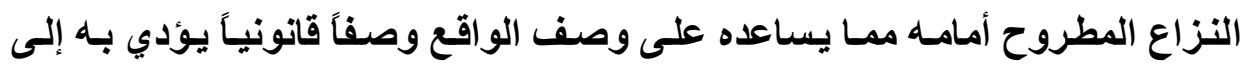

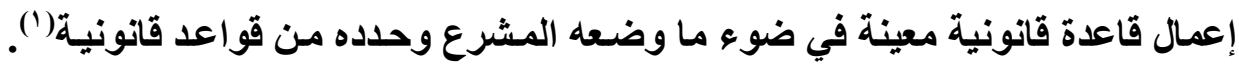
لذلك فقد كـان توجه الفقه و القضاء و التشريع بمنح القاضسي دوراً إيجابياً في مجـال المعاملات بما يعطي القاضي صلاحية التعديل في الالتزامات التي يتضمنها العقد سواء التهاء

(1) غازي الغثيان، سلطة القاضي التقيرية في تعديل مضمون العقا: دراسة مقارنة، رسالة ماجستير،

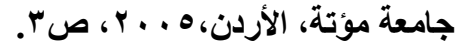


العدد ال (مارس_r.r.r) د/ماهرجابر-د/مراد محمودـ د/ أسماء مصطفى_ د/ عاطف سالم

في مرحلة التكوين أم التنفيذ بما في ذلك منح الأجل للمدين ليتمكن من تنفيذ التزامـه

ولكن بشرط ان تتوفر الشروط التي حددها المشرع في القانون(')

بالنتيجة فمتى توافرت جميع الثروط التي حددها المشرع والمتمثلة بعدم وجود

نص قانوني يمنع منح المهلة القضائية، وأن يكون المدين بحالـة تستدعي منحه مهلة للتمكن مسن الوفاء بالتزامسه، وألا يضر منـح المهلة القضائية بالائن ضرراً جسيماً، فللقاضي أن يمارس سلطته التقديرية ويمنح مهلة قضائية للمدين فهو حر في قراره بأن يمنحها أو يمنعها، كما أن له سلطة تقديرية في تحديد مدة نظرة الميسرة متى قرر منحها بشرط أن تكون معقولـة ومناسبة، بالإضـافة إلى حريتهـه في قراره بـأن يمنح

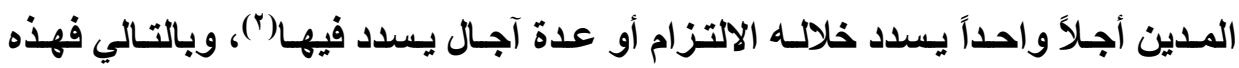
القواعد تعتبر من النظام العام التي لا تجيز للأفراد الاتفاق على سـلب القاضسي مثل تلك الصلاحيات ومتى حصل مثل ذلك الاتفاق يعتبر باطلاً.

بناء على ما سبق فإن قرار القاضي بمنح المهلة القضائية يعتبر صحيحاً متى تأكد من توافر تلك الشروط القانونيـة وبالتـالي فلا رقابـة لمحكمة التمييز على قرار قاضي الموضوع في منح مهلة الوفاء مع مراعاة ان تكون المدة التي منحهـا القاضي

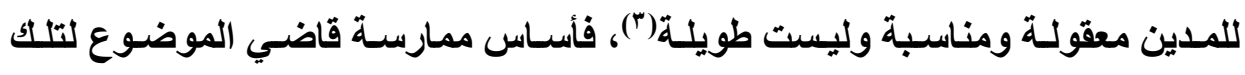
الصلاحيات هو نص المادة ء بr من القانون المدني الأردني التي أجازت له منح نظرة الميسرة للمدين وتحديد تلك المدة كذلك. وعليه فتعتبر مسألة منح المهلة القضائية مسألة من مسائل الواقع وليست مسألة من مسائل القانون ولذلك فهي تدخل في سلطة

$$
\begin{aligned}
& \text { (1) غازي الغثيان،مرجع سابق،صل. }
\end{aligned}
$$

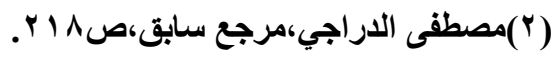

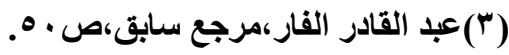




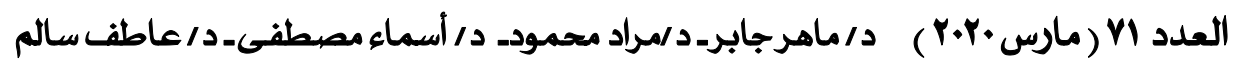

قاضـي الموضـوع ولا رقابـة لمحكـة التمييز على قـراره في هذه الحالـة، فلمحكـة الموضسوع السلطة في منح أو عدم منح المهلـة القضائية للمدين في حالـة تـوافرت الثروط التي حددها القانون في ضوء مـا يراه القاضـي لأن القاضـي عندما يقرر ذلك يكون مستعيناً بجميع ظروف اللدعوى وملابساتها. فـلا شـأن لمحكمـة التمييز بوقائع النزاع التي عرضت امام محكمة الموضوع، فهي مقيدة في ذلك إذ أن عليها أن تتقبل وقائع النزاع كمـا أثبتتهـا محكمة الموضوع وأصدر القاضـي قراره بشأن منـح الأجل وتعديله. 


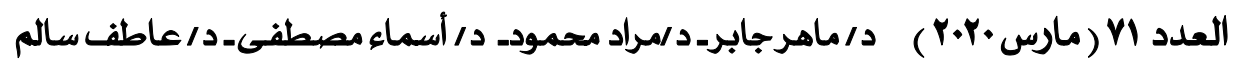

\section{الخاتمة والنتائج والتوصيات:}

لقد استعرضنا في هذا البحث مفهوم الأجل وأنواعه من حيث المصدر فهو إمـا أن يكون اتفاقياً أو قانونيا أو قضائيا. كما تطرقنا كذلك إلى أنواعه من حيث الأثر فهو إما أن يكون واقفاً أو فاسخًا. ايضاً تحدثنا عن الثروط اللازمة في الأجل وهي أن يكون مستقبلاً ومحقق الوقوع. وأخيراً بحثنا في الأجل القضائي أو مـا يسمى بنظرة الميسرة والتي تعد استثناءً على قاعدة أن العقد شريعة المتعاقدين حيث منح القانون سلطة تقديرية للقاضي لمنحها متى تحققت شروط منحها دون أن يكون قراره خاضعاً لرقابـة محكمة التمييز. من خلال هذه البحث توصلنا إلى عدد من النتائج تتمثل بما يلي: ا ـ أن المشرع الاردنـي أورد المواد التي تتعلق بأحكام الأجل دون التطرق لتعريف

$$
\text { الأجل على خلاف ما قعل مع الشرط. }
$$

r. أن المشرع الأردني اشترط توافر عدد من الشروط يجب أن تتوافر مجتمعة حتى يستطيع القاضي منح الأجل القضائي للمدين دون أن يكون قراره خاضعاً للمراجعة

من قبل محكمة التمييز.

r. أن المشرع في القانون المدني الأردني لم يحدد حداً أعلى للمهلة القضائية كما أنه لم يحدد حداً أدنى لها ايضا وإنما ترك أمر تحديدها من صلاحيات القاضي. وبناء على ما توصلنـا له في هذه الدراسة فإنتا نضع أمام المشرع الأردني عدداً من التوصيات عله يأخذ بها لمعالجة القصور الموجود في بعض نصوصه بخصوص الأجلوتتمثل تلكك التوصيات بما يلي: ا ـ نوصي المشرع بأن يضع نصاً خاصساً كمـا فعل عند معالجته للشرط يعرف من خلاله المقصود بالأجل القضائي أو نظرة الميسرة. 


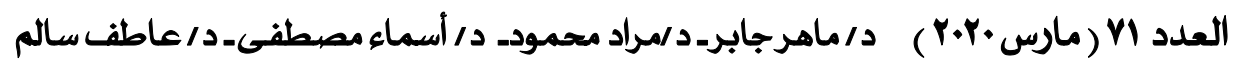

r. نوصي المشرع الأردني بأن يحصر قرار منح المهلة القضائية بالقاضسي وحده

$$
\text { دون حاجة لطلب المدين. }
$$

". نوصـي بـأن يحدد المشرع حداً أعلى للأجل فـلا يجعل الأمـر مطلقًاً لسلطات القاضي كما فعل في قانون وضع الأموال غير المنقولـة تأميناً للاين على سبيل

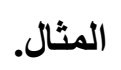

ع. نوصي المشرع بأن يحدد عدد الاجال التي يجوز للقاضي منحها للمدين بحيث لا تطول مدة المهلة القضائية فلا يضار الائن من ذلك.

•. كما نوصي ايضاً بـأن يحدد المشرع موعد بـأ سريان المهلة القضائية فليس واضحاً من النصوص القانونية موعد بدء تلك المدة، هل هو من تاريخ صدور قرار القاضي بمنحها؟ أم من موعد تبليغ الأطراف أصحاب العلاقة بها؟. 


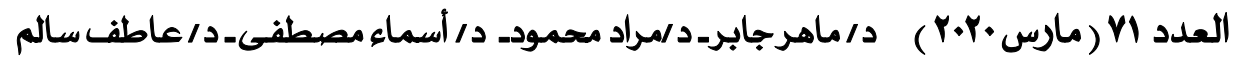

\section{المراجع}

1. أباليدن خوخة،انقاء الالتزام بالوفاء على ضوء الانون المدني الجزائري، رسالة

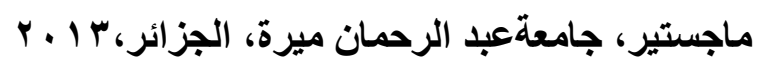

r. جلال العدوي،أحكام الالتزام دراسة مقارنة في القانونين المصري واللبناني، الدار

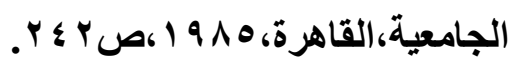

ץ. رمضان أبو السعود،أحكام الالتزام، دار الجامعة الجديدة، الإسكندرية، ؛ ... ؟،

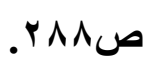

؛. طرطاق نورية، نظرة الميسرة في القانون المدني الجزائري، رسالة ماجستير،

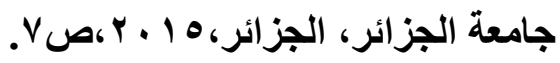

•.عامر الكسواني،أحكام لالتزامـ آثار الحقى في القانون المدني، دراسةمقارنة، دار

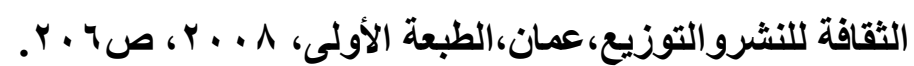

1. عبد الحكم فوده، إنهاء القوة الملزمة للعقد، (ب99 (1))، دار المطبوعات الجامعية،

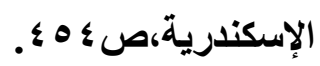

v. عبد الرحمن الحلالثشة، الوجيز في شرح القـانون المدني الاردني (اثـار الحق

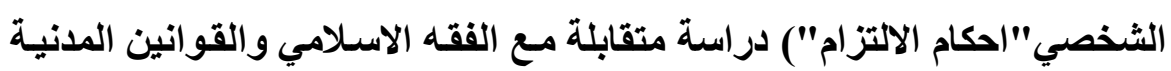

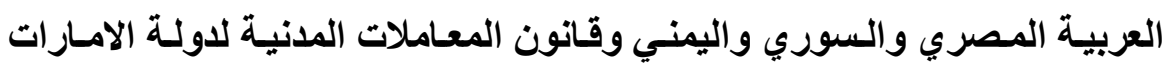

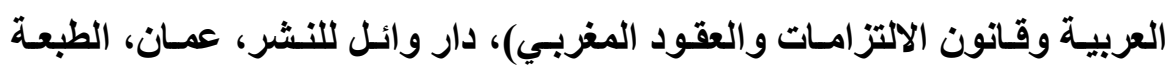

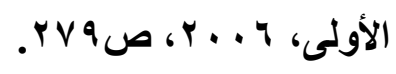




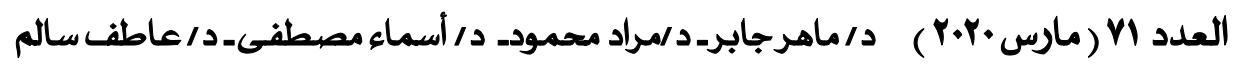

^. عبد الرحمن الحلالشة، المختصر في شرح القانون المدني الاردني اثـار الحق الثخصي" احكام الالتزام" دراسة مقارنة، دار وائل للنشر، عمان، الطبعة الأولى،

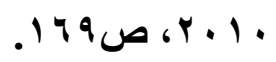

9. عبدالقادر الفار،أحكام الالتزام: آثار الحق في القانون الأردني، دار الثقافة للنشر

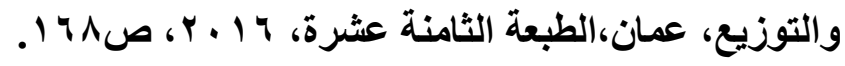

• 1 ـ غازي الغثيان، سلطة القاضي التقديرية في تعديل مضمون العقد: دراسـة مقارنـة،

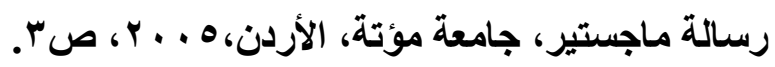

11 ـ مصطفى الدراجي، الالتزام الموصوف والقواعد التي تحكم تنفيذه. دراسـة مقارنـة

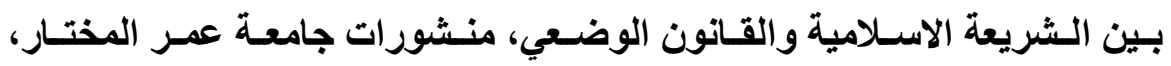

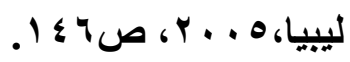

r ا ـ ياسـين الجبوري،المبسـوط فـي شــرح القــانون المــنـي،دار الثقافــة للنـشر

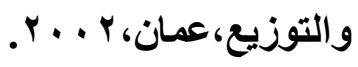

